Martínez-Gil, A., Cadahía, E., Fernández de Simón, B., Gutiérrez-Gamboa, G., Nevares, I., \& del Álamo-Sanza, M. (2018). Phenolic and volatile compounds in Quercus humboldtii Bonpl. wood: effect of toasting with respect to oaks traditionally used in cooperage. Journal of the Science of Food and Agriculture. https://doi.org/10.1002/jsfa.9190

\title{
Phenolic and volatile compounds in Quercus humboldtii Bonpl wood: Effect of toasting with respect to oaks traditionally used in cooperage
}

Ana Martínez-Gil ${ }^{\mathrm{a}, \mathrm{b}, 1^{*}}$, Estrella Cadahíac ${ }^{\mathrm{c}}$ Brígida Fernández de Simónc, Gastón Gutiérrez-Gamboa ${ }^{\mathrm{b}, \mathrm{d}}$, Ignacio Nevares ${ }^{\mathrm{f}, 1}$, María del Álamo-Sanza ${ }^{\mathrm{a}, 1}$

aaDepartamento de Química Analítica, Universidad de Valladolid, Avda. Madrid, 50, 34001 Palencia, Spain *e-mail: anamaria.martinez.gil@uva.es

${ }^{\mathrm{b}}$ Centro Tecnológico de la Vid y el Vino, Facultad de Ciencias Agrarias, Universidad de Talca, Av. Lircay S/N, Talca, Chile

'Centro de Investigación Forestal, CIFOR-INIA, Apdo 8111, 28080 Madrid, Spain ${ }^{d}$ Instituto de Ciencias de la Vid y del Vino (Gobierno de La Rioja-CSIC-Universidad de La Rioja). Carretera de Burgos Km. 6 (Autovía LO-20, salida 13). Finca La Grajera. 26007 Logroño, Spain

fDepartamento de Ingeniería Agrícola y Forestal, E.T.S. Ingenierías Agrarias, Universidad de Valladolid, Avda. Madrid, 50, 34001 Palencia, Spain

${ }^{1}$ Grupo UVaMOX, E.T.S. Ingenierías Agrarias, Universidad de Valladolid, Avda. Madrid, 50, 34001 Palencia, Spain

\begin{abstract}
BACKGROUND: The most frequent renewal of barrels of different origins and species is a current trend but this demand does not match the current availability of wood. An alternative could be the use of $Q$. humboldtii wood. However, there is little information about its composition. Due to this, the aim was to study low molecular weight phenols (LMWP), ellagitannins and volatile compounds in untoasted and toasted Q. humboldtii oak, and compare these with the species traditionally used in cooperage: $Q$. petraea (French and Romanian) and Q. alba (American).

RESULTS: The LMWPs in Q. humboldtii were comparable to those in Q. petraea and Q. alba. Ellagitannin composition in Q. humboldtii was similar to that in $Q$. alba. The toasting process improved volatile composition, mainly in $Q$. humboldtii, presenting the highest concentration of several volatile compounds.

CONCLUSION: The results indicate that $Q$. humboldtii could be considered suitable for aging wine, although it is necessary to continue the study of this wood species to confirm its potential use in oenology.
\end{abstract}

Keywords: ellagitannins, low molecular weight phenols, Quercus humboldtii, seasoning, toasting, volatile compounds. 


\section{INTRODUCTION}

Due to the constant search to improve wine quality, and the new trends in winemaking, the current predisposition is to use newer oak barrels of different origins and species. Therefore, demand for oak wood in oenology is constantly increasing, and in recent years an imbalance between the quantity of oak wood available and the number of oak barrels produced in cooperage has been detected. Thus, it is of interest and also necessary to study the use of different origins and species of oak wood rather than the traditional ones (French and American), as demonstrated by the number of studies focusing on this subject.

The extraction of different phenolic and volatile compounds from oak into the wine during aging depends mainly on the pool of potential extractable compounds originally present in the oak. The chemical composition of this oak is affected by two main groups of factors: on the one hand, the oak species, its geographical origin, and the silvicultural treatment of the tree, ${ }^{1-4}$ and on the other, the processing of the wood in cooperage, that is, the method used to obtain the staves, especially the degree of oak toasting during barrel manufacture, ${ }^{1,5,6}$, and also the method of seasoning (natural or artificial, length, and location). ${ }^{5,7}$

Low molecular weight phenols are important components of heartwood and contribute to the wood with color, smell, taste, and mechanical resistance properties. These compounds can also influence the color, astringency and bitterness of the wine. ${ }^{8}$ Ellagitannins are responsible for hardness and the avoidance of microbiological alterations in oak woods. ${ }^{9}$ These compounds can act as antioxidants in wines due to their ability to consume oxygen, ${ }^{10,11}$ although they degrade easily once solubilized in the wine, both in the presence and absence of oxygen, ${ }^{10}$ and may contribute to astringency and a sensation of bitterness. ${ }^{12-14}$ Volatile compounds play a key role in wine quality, especially regarding aroma, but their concentration depends on many factors, mainly the toasting process. ${ }^{15,16}$ This process modifies a wide range of compounds in the oak. Thus, a variety of mono- and dimethoxylated phenols, cinnamic acids, benzoic acids, and aldehydes are formed from the lignin degradation by hydrolytic and oxidative processes. This degradation would contribute to an increase in the levels of phenolic aldehydes and volatile compounds, degrading ellagitannins. ${ }^{17}$

An interesting alternative source of oak wood could be $Q$. humboldtii from Colombia, which is currently used for the aging of alcoholic drinks such as Rum or Brandy. ${ }^{18}$ Nowadays, certain cooperage companies which provide this type of oak wood for the aging of distilled beverages are trying to sell this wood to the wine industry on the basis that it is of the same quality as that traditionally used for aging wine. Moreover, the usual method of seasoning this wood in cooperage is artificial as an oven is used.. However, there is little information about Q. humboldtii in winemaking, and it has only been found that its wood showed similar vanillin concentrations to $Q$. faginea, and a balanced syringaldehyde/vanillin relationship, a marker usually used to characterize quality oak wood, suggesting that $Q$. humboldtti has potentially good properties for wine aging. ${ }^{19}$ Moreover, the phenolic composition of green Q. humboldtii has been characterized as and compared to traditional oak with the most abundant phenolic acids, aldehydes and ellagitannins being the same as in traditional oak wood (Q. alba and $Q$. petraea), and with a phenolic composition closer to American ones. ${ }^{20}$ On the other hand, to our knowledge there is no information that characterizes other low molecular weight phenolic, ellagitannins and volatile compounds in untoasted and toasted Q. humboldtii oak, so this study could provide more knowledge and information of interest.

As already mentioned, various authors have studied certain oak wood sources of different origin and species with the aim of providing information about other types of 
oak as an alternative to French (Q. petraea and Q. robur) and American (Q. alba) oaks, which have traditionally been used in winemaking. Hungarian and Russian oak woods have been shown to have a lower content of oak lactones, trans and cis-isoeugenol, and higher odor intensities than the American and French ones. ${ }^{21}$ The unheated volatile concentration of Portuguese (Q. pyrenaica) oak wood was lower than that of French $(Q$. petraea) and American (Q. alba) ones; however, its content improved greatly after the toasting process. ${ }^{16}$ Quantitative differences were found in low molecular weight phenolic, especially in American (Q. alba) species compared to the Spanish (Q. robur, $Q$. petraea, Q. pyrenaica, and Q. faginea) and the French $(Q$. robur, and $Q$. petraea) ones. ${ }^{7}$ Prida and Puech ${ }^{3}$ observed that East European wood held an intermediate position between American and French oaks according to their ellagitannins and oak lactone levels, and are characterized by high values of eugenol, aromatic aldehydes and 2phenylethanol.

For these reasons, the aim of this study was to evaluate the low molecular weight phenols, and ellagitannins by HPLC-DAD, and volatile compounds by GC-MS of untoasted and toasted oak wood of $Q$. humboldtii (Colombian oak), and to compare it to the species traditionally used in cooperage, such as Q. petraea (French oak) and Q. alba (American oak) as well as others more recently introduced (Q. petraea from Romania).

\section{MATERIALS AND METHODS Wood samples}

For this study, four different oak woods (origin and/or species) were used: Quercus petraea (Matt.) Liebl. (called French and Romanian oak), Quercus alba L. (called American oak) and Quercus humboldtii Bonpl (called Colombian oak). French, Romanian, American oaks were imported to Chile as green wood to the cooperage, Tonelería Nacional Chile LTDA. Therefore, the drying of these woods was carried out as usually done by this cooperage for oak wood. This process is a natural seasoning in the open air for 30 months, watering daily in summer according to the cooperage procedure. After seasoning these stave woods presented humidity between 11 and $13 \%$. On the other hand, the Colombian oak staves were imported after a semi-accelerated seasoning process as usual in cooperage when this oak is used for brandy and rum aging. This accelerated seasoning is carried out with steam in special chambers, where the temperature gradually increases, starting with a temperature of $22{ }^{\circ} \mathrm{C}$ in the first few days of drying and ending with a temperature of $60{ }^{\circ} \mathrm{C}$. This process is finished when the moisture content of the wood (MC) is approximately 12 to $14 \%$, which takes approximately 3 weeks. Then the oven is turned off, and the wood is slowly adjusted to room temperature (36-48 hours).

After seasoning, all the kinds of wood staves were toasted in an industrial-scale convection oven, normally used by the cooperage for alternative products. Toasting was defined by this cooperage as medium-plus toasting, which consists of a temperature ramp up to $200^{\circ} \mathrm{C}$ and for a total of 140 minutes.

Three representative batches of each type of wood were prepared for the chemical analyses. Six pieces were taken from each batch of wood and ground, sawdust was obtained using a planer-thicknesser and this was sieved and mixed, taking the sawdust ranging in size from 0.80 to $0.28 \mathrm{~mm}$ as the representative batch sample. A total of 12 representative samples were studied for different oak woods $(Q$. petraea from France and Romania, Q alba, Q. humboldtii) before toasting (defined as non-toasted) and another 12 representative samples after toasting (defined as toasted). 
Martínez-Gil, A., Cadahía, E., Fernández de Simón, B., Gutiérrez-Gamboa, G., Nevares, I., \& del Álamo-Sanza, M. (2018).

Phenolic and volatile compounds in Quercus humboldtii Bonpl. wood: effect of toasting with respect to oaks traditionally used in cooperage. Journal of the Science of Food and Agriculture. https://doi.org/10.1002/jsfa.9190

\section{Standards}

In the case of low molecular weight phenolic compounds, reference compounds were purchased from Fluka Chemie AG (Buchs, Switzerland) (gallic acid), Sigma Aldrich (Steinheim, Germany) (vanillic acid, syringic and coniferyl aldehydes), Apin (ellagic acid), Chem Service (West Chester, PA) (syringic acid), Extrasynthèse (Genay, France) (sinapaldehyde). For ellagitannins, standards of vescalagin, castalagin, roburin A and E, and grandinin were used. For volatile compounds, all standards ( $\gamma$-hexalactone, 2octanol, 4,5-dimethylfurfuraldehyde, o-vanillone, 3,4-dimethoxyphenol, furfural, 5methylfurfural, 5-hydroxymethylfurfural, furfuryl alcohol, trans- $\beta$-methyl- $\gamma$-octalactone, cis- $\beta$-methyl- $\gamma$-octalactone, guaiacol, 4-ethylguaiacol, 4-vinylguaiacol, eugenol, cisisoeugenol, trans-isoeugenol, syringol, vanillin, acetovanillone, benzaldehyde and 2phenylethanol) were provided by Sigma Aldrich (Steinheim, Germany).

\section{Low molecular weight phenols and ellagitannin extractions}

The sawdust samples $(1 \mathrm{~g})$ were extracted with $100 \mathrm{~mL}$ of methanol/water (1:1) at room temperature and in darkness for 24 h, using the method described by Fernández de Simón et al. ${ }^{22}$ for low molecular weight phenols and by Fernández de Simón et al. ${ }^{23}$ for ellagitannins. After removal of the methanol in a rotary evaporator at a temperature below $40{ }^{\circ} \mathrm{C}$, the aqueous solution was extracted with diethyl ether and ethyl acetate and then freeze-dried. The diethyl ether and ethyl acetate extracts were taken to dryness, dissolved in methanol/water (1:1) and used for the HPLC quantitative determination of low molecular weight phenolic compounds (ellagic, gallic, syringic and vanillic acids and coniferyl, sinapic and syringic aldehydes), and the freeze-dried aqueous extract for that of ellagitannins (castalagin, vescalagin, grandinin, roburin A, B, C, D and E).

\section{Analysis of low molecular weight phenols and ellagitannins by HPLC-DAD}

Low molecular weight phenols were analyzed using the method explained by Cadahía et al. ${ }^{7}$ and ellagitannins according to the method of Cadahía et al. ${ }^{24}$ An Agilent 1200 HPLC equipped with a diode array detector and a C18 Hypersyl ODS (5 $\mu \mathrm{m})$ column (20 cm $\times 4 \mathrm{~mm}$ i.d.), protected with a precolumn of the same material, was used. Low molecular phenols: the elution conditions were modified as follows: flow rate, 1 $\mathrm{mL} / \mathrm{min}$; temperature, $30{ }^{\circ} \mathrm{C}$; solvent $\mathrm{A}=\mathrm{H}_{2} \mathrm{O} / \mathrm{PO}_{4} \mathrm{H}_{3}$ (999:1), solvent $\mathrm{B}=\mathrm{MeOH} / \mathrm{PO}_{4} \mathrm{H}_{3}$ (999:1) and a linear gradient was used, 0 to $100 \%$ B, in $70 \mathrm{~min}$. Detection was at $325 \mathrm{~nm}$ (with a bandwidth of $150 \mathrm{~nm}$ ) and UV spectra $(240-400 \mathrm{~nm}$ ) were also recorded. Chromatographic peaks were identified by comparing their retention time and the UV spectra with those of reference compounds and quantitative determinations were carried out by the external standard method. Ellagitannins: a gradient profile was used, 0-10\% B in $0-40 \mathrm{~min}, 10-30 \% \mathrm{~B}$ in $40-70 \mathrm{~min}, 30-100 \% \mathrm{~B}$ in $70-90 \mathrm{~min}$; and detection was at 325 $\mathrm{nm}$ (with a bandwidth of $150 \mathrm{~nm}$ ). Quantitative determinations were carried out in accordance with the external standard method. Roburins B-D were expressed as roburin A because they are also dimers.

\section{Volatile compound extraction}

Maceration to extract the volatile compounds from sawdust was based on the method described by Chatonnet et al. ${ }^{25}$ The sawdust samples ( $2 \mathrm{~g}$ ) were soaked in 100 $\mathrm{mL}$ of hydroalcoholic (12\% ethanol, $6 \mathrm{~g} \mathrm{~L}^{-1}$ tartaric acid, $\mathrm{pH}$ 3.2) for 15 days at a room temperature of $20^{\circ} \mathrm{C}$ in darkness. After filtration of the mixture $300 \mu \mathrm{L}$ of five internal standards were added ( $\gamma$-hexalactone, 2-octanol, 4,5-dimethylfurfuraldehyde, ovanillone, and 3,4-dimethoxyphenol at a dose of $0.5 \mathrm{mg} \mathrm{mL}^{-1}$ in ethanol). The hydroalcoholic solution with the oak aromas and the standards were then extracted using 
a previously reported methodology. ${ }^{26}$ For that, prepacked cartridges (total volume $3 \mathrm{~mL}$ ) filled with 200 mg of LiChrolut EN resin (Merck, Darmstadt, Germany) were used.

\section{Analysis of volatile compounds by GC-MS}

The separation, identification and quantification of volatile compounds from the wood extract were carried out using an Agilent 7890A gas chromatograph, coupled with a 5975C mass spectrometer (Agilent Technologies Inc., Santa Clara, CA, USA). The unit was equipped with a fused silica capillary column $(60 \mathrm{~m} \times 0.25 \mathrm{~mm}$ i.d., and $0.5 \mu \mathrm{m}$ phase thickness, DB-Wax, J \& W Scientific, Agilent). The carrier was helium applied at a flow rate of $1 \mathrm{~mL} \mathrm{~min}^{-1}$. The temperature of the injector was $250{ }^{\circ} \mathrm{C}$ and $1 \mu \mathrm{L}$ of oak or wine extract was injected. The oven temperature was initially held at $40^{\circ} \mathrm{C}$ for $5 \mathrm{~min}$, then increased linearly at a rate of $2{ }^{\circ} \mathrm{C} \min ^{-1}$ up to $130{ }^{\circ} \mathrm{C}$ and held at that for $5 \mathrm{~min}$; after that, it was again increased at a rate of $2^{\circ} \mathrm{C} \mathrm{min}{ }^{-1}$ up to $180^{\circ} \mathrm{C}$ and held for $2 \mathrm{~min}$; finally, i was increased linearly at a rate of $4^{\circ} \mathrm{C} \mathrm{min}{ }^{-1}$ up to $230 \mathrm{~min}$. Two injections were carried out: one in split mode (50:1) for furfural and 5-methylfurfural and the other in splitless mode for the rest of the volatile compounds analyzed (5-hydroxymethylfurfural, furfuryl alcohol, trans- $\beta$-methyl- $\gamma$-octalactone, cis- $\beta$-methyl- $\gamma$-octalactone, guaiacol, 4ethylguaiacol, 4-vinylguaiacol, eugenol, cis-isoeugenol, trans-isoeugenol, syringol, vanillin, acetovanillone, benzaldehyde and 2-phenylethanol). Ionization was by electron impact at $70 \mathrm{eV}$. The operating method was a scan mode at $\mathrm{m} / \mathrm{z}$ between 30 and 300 . The NIST library was used for identification. Quantification was based on eight-point calibration curves of the respective standards (Sigma-Aldrich, Steinheim, Germany) $\left(\mathrm{R}^{2}\right.$ $>0.95)$ in a $12 \%(\mathrm{v} / \mathrm{v})$ ethanol solution with $6 \mathrm{~g} \mathrm{~L}^{-1}$ of tartaric acid at $\mathrm{pH} 3.2$; analyzed under the same conditions.

\section{Statistical analysis}

This was carried out using the SPSS Version 21.0 statistical package for Windows (SPSS, Chicago, USA). Low molecular weight phenol, ellagitannins and volatile compounds were processed using variance analysis (ANOVA). Differences between means were compared using the Duncan test at 0.05 probability level. Principal component analysis (PCA), using Stagraphics Centurion 16.2.04, StatPoint Technologies, Inc. (Warrenton, United States), was performed individually with the low molecular weight phenol, ellagitannins and volatile compounds in the non-toasted and toasted woods.

\section{RESULTS AND DISCUSSION}

\section{Low molecular weight phenol content in oak woods}

Table 1 shows the LMWP obtained in Q. petraea (French and Romanian oaks), Q. alba (American oak) and Q. humboldtii (Colombian oak) woods after seasoning (nontoasted) and toasting.

The most abundant low molecular weight phenols in non-toasted wood were ellagic acid followed by gallic acid (Table 1). In toasted oak wood, the most abundant compounds were ellagic acid, sinapic aldehyde and coniferyl aldehyde. This result, both in non-toasted and toasted woods, coincides with that observed by other authors. ${ }^{7}$

Ellagic acid concentration in non-toasted wood showed non-significant differences among the different species or origins, and represented 68 to $90 \%$ of total LMWP (Colombian and American oaks, respectively). These results are in agreement with those described in the bibliography in Q. petraea and Q. alba. ${ }^{7}$ However, non-toasted Colombian oak presented the highest gallic acid concentration, with approximately twice as much as that in the other oaks. Therefore, gallic acid contribution to the total LMWP 
was high in Colombian oak (29\%), whilst being 10-18\% (Rumanian and French, respectively) in Q. petraea and only $2 \%$ in American oak. The other acids studied found at lower concentrations -, syringic and vanillic acid had lower concentrations in $Q$. humboldtii, except in the case of vanillic acid in Romanian oak which presented a similar concentration (Table 1).

Thus, total concentration of phenolic acids in non-toasted woods was higher in $Q$. humboldtii than in Q. alba; however, no significant differences were found when comparing $Q$. humboldtii to Q. petraea (Table 1). The phenolic acids in $Q$. petraea and Q. alba after the toasting process presented higher or similar concentrations to those found before toasting (non-toasted), these results being similar to those observed by Cadahía et al. ${ }^{7}$ Therefore, the toasting process increased the total phenolic acids in these oak species (Q. petraea and Q. alba,) by between 45 and $69 \%$. Table 1 shows that syringic and vanillic acids increased in all oak woods due to the toasting process, while ellagic acid only did so in Q. petraea from France and Q. alba, since the concentration in $Q$. petraea from Romania and Q. humboldtii remained constant. However, gallic acid concentration in Q. alba and in Q. petraea from Rumania increased, remained constant in French oak wood and even decreased in the case of Colombian oak: after toasting this was approximately $68 \%$ in $Q$. humboldtii , which showed a decrease of $16 \%$ of total phenolic acids (Table 1). The concentration of some compounds, like gallic acid, has been seen to increase in Acacia heartwood after light and medium toasting, but to decrease at a higher toasting intensity ( $185{ }^{\circ} \mathrm{C}$ for $\left.45 \mathrm{~min}\right) .{ }^{27}$ In this study, the toasting intensity is the same for all oaks, with all of them being toasted at the same time in the same oven. The differences could thus be because this oak may have a different composition in compounds not studied in this work, possibly lignin.

After toasting ellagic acid had the highest content but its contribution to the total LMWP decreased with toasting, representing around 22 to $35 \%$ of the total(Colombian and French oaks, respectively). This was due to the increase of other compounds by toasting being higher (coniferyl and sinapic aldehydes). Ellagic acid was higher in French oak than in American wood, an already known fact; moreover, its concentration in Colombian oak was similar to that in the American one. Although after seasoning the Colombian oak had the highest gallic acid, after the toasting process this and the American were those with the lowest concentration of this compound. Though $Q$. humboldtii oak before seasoning had low syringic and vanillic acid concentrations, after toasting it had the highest content, but syringic acid showed no differences in comparison with French oak. Consequently, Colombian toasted wood presented a similar total concentration of phenolic acids to American oak, and lower than Q. petraea but only significantly as regards French wood (Table 1).

With respect to the aldehydes, the non-toasted Colombian oak together with the Romanian were those with the lowest concentrations of coniferyl and syringic aldehydes. However, $Q$. humboldtii had the highest sinapic aldehyde content.

Table 1 shows that $Q$. alba was the oak with the highest concentration of total aldehydes in non-toasted woods. Aldehydes showed a significant increase in their concentration after toasting. This result coincides with that observed by Cadahía et al. ${ }^{7}$ The highest increase of LMWP from seasoning to toasting was observed in the total aldehyde content, increasing from 1263 to $1799 \mu \mathrm{g} \mathrm{g}^{-1}$ of wood (Romanian and Colombian oaks, respectively). The total phenolic aldehyde content did not show any significant differences among species or origins after toasting (Table 11).

Thus, after the toasting process, coniferyl and sinapic aldehydes did not show any significant differences among the different species or origins. These two compounds were those that increased most during toasting, so sinapic aldehyde contributed a great deal to 
the total LMWP representing around 38 to 47\% (Romanian and Colombian oaks, respectively) and coniferyl aldehyde was around 15 to 22\% of total LMWP (Q. petraea and Q. alba, respectively). However, although the syringic aldehyde concentration was low in $Q$. humboldtii before toasting, this oak showed the highest concentration after this process, but without any significant differences with respect to Q. alba (Table 1).

Thus, syringic aldehyde and vanillin are considered as markers for the aging of distilled beverages since they are useful for evaluating the quality of aged ones. ${ }^{28,29}$ In addition, during the aging of wines in oak barrels, lignin is degraded into syringic aldehyde and vanillin, the latter contributing to the vanilla flavors typical of all wines aged in oak barrels. ${ }^{30}$ Puech and Jouret ${ }^{31}$ reported that a syringic aldehyde/vanillin ratio between 1.4 and 2.5 indicates a balance between the products of lignin degradation. In our samples, this ratio ranged from 1.51 to 4.74 in the Q. alba and Q. humboldtii oak woods (Table 1 and 3); however, this ratio was 3.49 in Q. petraea of French origin, and 3.06 in $Q$. petraea from Romania, being higher in all oak woods except $Q$. alba than that reported by Puech and Jouret ${ }^{31}$ in different species of toasted oak woods, and higher than that obtained by González et al. ${ }^{19}$ in $Q$. humboldtti toasted oak wood.

The principal component analysis (PCA), shown in Figure 1, was carried out to evaluate the discriminant power of LMWP for the four kinds of oak wood studied before (a) and after (b) the toasting process.

Before toasting, the percentage of variance was $77.01 \%$ with two components (principal components 1 and 2 explaining $58.72 \%$ and $19.00 \%$ of the variance, respectively). Component 1 shows a wide distance between $Q$. humboldtii with respect to Q. petraea and Q. alba (Figure 1a). It has been noted that the most significant parameters to differentiate $Q$. humboldtii oak from the traditional ones were gallic acid, sinapic aldehyde and ellagic acid. The second component was principally correlated positively to syringic, gallic and vanillic acids, with the French oak being located more on the positive side of the second component axis.

The percentage of variance in Figure 1b (PCA of toasted woods) was 87.79\%, component 1 explained 57.04\% of the variance and component 2 26.74\%. Component 1 has a closer negative correlation with syringic acid, vanillic acid, coniferyl aldehyde, sinapic aldehyde and syringic aldehyde with Q. humboldtii, the oak situated furthest to the left of the negative side of the first principal component axis. The second component did not differentiate either species or origin.

Considering this, it can be observed that the Colombian wood differentiated very clearly from the rest of the species before toasting, which may be due to a different composition of the fresh wood or to the different seasoning method used. However, after the toasting treatment there is a greater similarity in its composition to the species traditionally used in cooperage, especially since ellagic acid decreased its contribution to total LMWP and increased the contribution of coniferyl and sinapic aldehydes with the last two compounds having similar concentrations in all the species studied.

\section{Ellagitannins}

Table 2 shows ellagitannin compounds obtained from Q. petraea (French and Romanian oaks), Q. alba (American oak) and Q. humboldtii (Colombian oak) after seasoning and toasting.

The most abundant ellagitannin compounds in non-toasted woods were castalagin and vescalagin as reported by Glabasnia and Hofman. ${ }^{12}$ Castalagin represented 29 to $34 \%$ of total ellagitannins in non-toasted oak woods (French and Colombian oaks, respectively). Vescalagin represented 17 to $35 \%$ of total ellagitannins in non-toasted oak woods (Colombian and French oaks, respectively). The compound with the next highest 
concentration was roburin D, 14 to $20 \%$ of total ellagitannins (French and American oaks, respectively). Therefore, it could be stated that the relationship between the different ellagitannins in Q. humboldtii is of the same order as in traditional oak woods. As in nontoasted wood, the major ellagitannins in traditional toasted oaks were castalagin and vescalagin, these results being consistent with those observed by other authors ${ }^{3,32}$. Castalagin presented 63 to $54 \%$ of total ellagitannins in traditional toasted oak woods (American and Rumanian oaks, respectively) and vescalagin 25\% to 15\% (French and American oaks, respectively). However, after toasting the Colombian oak did not present the same relationship with respect to traditional ones among ellagitannins, since castalagin and vescalagin represented 15 to $11 \%$ of total ellagitannins, respectively. The major compounds in this oak were roburin D and grandinin with 38 to $22 \%$ of the total. Roburin C was the lowest quantified ellagitannin in non-toasted and toasted oak wood, as reported by Cadahía et al., ${ }^{24}$ this compound also being the lowest in Q. humboldtii oak (Table 2). This concentration represented 0.9 to $4.9 \%$ of total ellagitannin compounds in non-toasted oak woods (French and American oaks, respectively), and 0.5 to $1.8 \%$ in toasted ones (French and American oaks, respectively).

Regarding the quantitative contents in the composition of non-toasted oak woods, $Q$. humboldtii and Q. alba presented a lower concentration of monomers (castalagin and vescalagin), pentosylated monomers (grandinin and roburin E), dimers (roburin A+B) and roburin D than $Q$. petraea. Also, $Q$. humboldtii showed the lowest roburin C content after $Q$. alba. In addition, differences due to geographical origin were found, since French oak showed higher castalagin, vescalagin, roburin $\mathrm{E}$ and roburin $\mathrm{A}+\mathrm{B}$ concentrations than Rumanian wood, though they are the same species (Q. petraea) (Table 2).

In relation to the ellagitannin composition in toasted oak woods, the differences were similar in comparison with that found in non-toasted oak woods. Q. humboldtii and Q. alba were those with the lowest content of each ellagitannin, although in this case without any significant differences with respect to Romanian oak as regards some (roburin E and roburin D), or in grandinin when compared to French oak. Thus, comparing toasted $Q$. petraea of both origins, French oak presented a higher content of castalagin, vescalagin, and roburin $A+B$, while exhibiting lower amounts of grandinin than Romanian oak wood; these differences due to geographical origin were also observed by Prida and Puech.

Therefore, total ellagitannin concentration in non-toasted and toasted oak wood was lower in Q. humboldtii and Q. alba than in Q. petraea (Table 2). Total ellagitannin content decreased during toasting in all oak wood species. During the toasting process, a variety of hydrothermolysis and pyrolysis reactions take place degrading wood constituents, including ellagitannins. ${ }^{33}$ In addition, it has been shown that roburins A-E, grandinin, vescalagin, and castalagin decreased during toasting ${ }^{24}$ with this decrease usually being higher when the toasting temperature increases. ${ }^{32}$ It ranged from 83 to $87 \%$ in wood traditionally used in cooperage, and decreased by $92 \%$ in $Q$. humboldtii oak wood in our samples at $200^{\circ} \mathrm{C}$. Thus, the toasting process affects the ellagitannin composition of $Q$. humboldtii more than the rest of the oak woods studied. These results concerning ellagitannin content in toasted Q. alba and Q. petraea oaks have also been reported by several authors. ${ }^{3,24,32}$

Another principal component analysis (PCA) was carried out to evaluate the discriminant power of ellagitannins for the four kinds of oak wood studied, before (Figure 2a) and after (Figure 2b) toasting. PCA was defined mainly by one component, since component 1 was $93.48 \%$ and $82.73 \%$ of variance, respectively (non-toasted and toasted woods), and the second component was $4.50 \%$ and $14.71 \%$, respectively. The main component (PC 1) differentiated the European oaks from the Q. humboldtii and Q. alba 
woods and has a closer positive correlation with all ellagitannins in both non-toasted and toasted woods. However, component 2 in the non-toasted wood principally differentiated the American from the Colombian oak. This component is especially correlated positively with vescalagin, castalagin, A, B and E roburins. Once toasted, the composition of the Colombian wood resembled American oak even more; thus neither component could separate these two oaks. Moreover, after the toasting process, component 2 separated the French oaks from the Romanian ones. This was positively correlated with grandinin and roburin C, thus defining Romanian oak. In addition, a high variability in $Q$. petraea (French and Romanian oaks) was observed, which has been reported by several authors. ${ }^{24}$ However, Q. alba and Q. humboldtii presented similar compound concentrations.

\section{Volatile compounds}

Table 3 shows the volatile compounds in Q. petraea (French and Romanian oaks), Q. alba (American oak) and Q. humboldtii (Colombian oak) in non-toasted and toasted woods.

The most abundant volatile compounds in non-toasted wood were 5hydroxymethylfurfural, vanillin, trans- $\beta$-methyl- $\gamma$-octalactone, and cis- $\beta$-methyl- $\gamma$ octalactone, which represented 85 to $88 \%$ in the oak woods traditionally used in cooperage but $18 \%$ in $Q$. humboldtii. These compounds also presented high concentrations in non-toasted French and American oaks in the study by Fernández de Simón et al. ${ }^{4}$ Table 3 shows that furfural was not detected in these non-toasted oak wood samples. Also 5-hydroxymethylfurfural or trans- $\beta$-methyl- $\gamma$-octalactone were not detected in the Colombian non-toasted wood nor was guaiacol in Q. petraea. Furfuryl alcohol, 4-ethylguaiacol, 4-vinylguaiacol, and cis-isoeugenol did not show any statistical differences among the studied non-toasted oak woods. Cadahía et al. ${ }^{5}$ found similar concentrations of these compounds in non-toasted oaks and also no significant differences between Q. petraea from France and Q. alba. Non-toasted Q. humboldtii wood presented the lowest concentration of vanillin after $Q$. petraea, with the highest one in $Q$. alba oak (Table 3). Moreover, Q. alba showed the highest content of cis- $\beta$-methyl- $\gamma$-octalactone, acetovanillone, benzaldehyde, and 2-phenylethanol, and these compounds did not show any significant differences between Q. petraea and Q. humboldtii. However, Q. petraea non-toasted oak wood presented the highest concentration of 5-hydroxymethylfurfural while French wood had the lowest one and Romanian oak showed the highest concentration of trans- $\beta$-methyl- $\gamma$-octalactone. Finally, $Q$. humboldtii wood evidenced the highest content of guaiacol, and trans-isoeugenol.

However, in toasted oak wood the most abundant compounds were furfural, 5methylfurfural, 5-hydroxymethylfurfural, cis- $\beta$-methyl- $\gamma$-octalactone and vanillin. These represented 96 to 99\% of total volatile compounds (Colombian and French oak, respectively). In contrast, 4-ethylguaiacol, benzaldehyde and 2-phenylethanol showed the lowest abundance in toasted oak woods, and represented 0.03 to $0.10 \%$ of total volatile compounds ( $Q$. petraea of Romanian origin and $Q$. humboldtii, respectively).

Regarding toasted oak woods, 2-phenylethanol was the only compound that did not show any significant differences in concentration among the different origins and species. In toasted wood, Q. humboldtii exhibited higher amounts of several volatile compounds with respect to the other oak woods studied. These compounds were 5methylfurfural, furfuryl alcohol, guaiacol, 4-ethylguaiacol, 4-vinylguaicol, cisisoeugenol, trans-isoeugenol and syringol. In addition, this oak also presented the highest concentrations of eugenol together with the Romanian one. Prida and Puech ${ }^{3}$ also observed a higher eugenol content in Q. petraea from Romania than that from France and $Q$. alba. The odor descriptors usually used to characterize the aromatic contribution 
of these compounds in wines are almond, caramel, moldy hay, burnt sugar, honey, smoke, phenolic, spice, flower, pink pepper and clove. ${ }^{34,35}$ However, Q. humboldtii showed the lowest furfural, 5-hydroxymethylfurfural and cis- $\beta$-methyl- $\gamma$-octalactone concentrations, compounds with bread, almond, sweet, oaky, coconut and vanilla aroma notes. ${ }^{34}$ On the other hand, Q. alba toasted oak wood presented the highest concentration of furfural, cis$\beta$-methyl- $\gamma$-octalactone, vanillin, acetovanillone and benzaldehyde. The fact that furfural and/or cis- octalactone are found in high concentrations in American oak has been observed by other authors ${ }^{3-5,36-38}$; however, as regards vanillin and benzaldehyde this is not clear since some of these authors found a higher concentration in $Q$. alba and others in $Q$. petraea. Romanian oak wood evidenced the highest content of 5hydroxymethylfurfural, and trans- $\beta$-methyl- $\gamma$-octalactone.

Therefore, total volatile composition in non-toasted woods was lower in $Q$. humboldtii than traditional oaks, with significant differences with respect to Q. alba and $Q$. petraea from Romania; however, none were found when compared to French $Q$. petraea (Table 3). The toasting process increased the volatile composition of oak wood, as has been reported by various authors. ${ }^{4,5}$ A perceptible increase due to the toasting treatment was higher in the $Q$. humboldtii oak wood, since its initial concentration increased 103 times, followed by Q. petraea of both origins (France and Romania), which showed a 49-fold increase, and finally $Q$ alba with a 29-fold increase. In spite of the high increase due to toasting, total volatile composition in the Colombian wood remained significantly lower than in Q. petraea from Romania and Q. alba, but statistically similar to Q. petraea from France (Table 3). This was due to the compounds whose concentration increased most after toasting which were furfural and 5-hydroymethylfurfural, representing $90-96 \%$ of the total volatile composition after toasting, while $Q$ humboldtii and Q petraea from France had lower concentrations of these. Other authors, Cadahía and Fernández de Simón, ${ }^{39}$ also reported that these two compounds were the most abundant in toasted oak woods.

The last principal component analysis (PCA) was performed with the aim of identifying and evaluating the volatile compounds as this could differentiate oak according to species and origin, Q. petraea (French and Romanian oak), Q. alba (American oak) and Q. humboldtii (Colombian oak) before and after toasting (Figures 3a and $b$, respectively). These figures provide a graphical representation of the oak sample projections for each group on a plane defined by two main components ( 1 and 2). Before toasting, the percentage of variance was $68.71 \%$ with two components (component 1 explained 36.65\% of the variance and 2 explained 32.06\%). After toasting, the percentage of variance was $73.87 \%$ with two components (component 1 explained $51.05 \%$ of the variance with component 2 explaining 22.82\%). It shows a wide distance between $Q$. humboldtii with respect to Q. petraea and Q. alba samples, both before and after toasting, since component 1 had the most weight of variance. This component could only separate $Q$. humboldtii from the traditional ones. Q. humboldtii in figure 3a (non-toasted PCA) was located on the negative side of the first principal component axis defined by guaiacol, 4-ethylguaiacol, eugenol, trans-isoeugenol, cis-isoeugenol, vanillin and 5methylfurfural; however, in figure 3b (toasted PCA) Q. humboldtii samples were located on the positive side of first principal component axis defined, like the other PCA, by guaiacol, 4-ethylguaiacol, trans-isoeugenol, cis-isoeugenol and 5-methylfurfural and also by 5-methylfurfural, 4-vinylguaiacol, and syringol. In this figure, component 1 again shows what is described above about the different behavior of the Colombian wood after toasting when compared to the woods traditionally used in cooperage for wine.

In both cases (non-toasted and toasted) Q. alba oaks and Q. petraea ones (French and Romanian) were separated in component 2, while $Q$. humboldtii wood was situated 
between the two, being closer to Q. petraea, especially after toasting (Figure 3). As regards this component, non-toasted and toasted $Q$. petraea woods were defined by furfural, trans- $\beta$-methyl- $\gamma$-octalactone and 5-hydroxymethylfurfural. Before toasting they were also defined by syringol and after toasting by eugenol, cis-isoeugenol and 5methylfurfural.

According to the information provided by the variables related to PCA 1, and PCA 2 it has been concluded that $Q$. humboldtii wood volatile composition differed from that of Q. petraea and Q. alba oak woods while being more similar to European woods than American ones.

\section{CONCLUSION}

Q. humboldtii (Colombian oak) showed interesting attributes of quality in relation to its low molecular weight phenolic, ellagitannins and volatile composition, points to be considered for cooperage. Non-toasted Q. humboldtii oak wood evidenced the same concentration of total phenolic acids and aldehydes as $Q$. petraea.The total low molecular weight phenols concentration in the toasted Colombian oak was statistically similar to the other oak woods Total ellagitannin concentration in non-toasted and toasted $Q$. humboldtii and Q. alba oak woods was much lower than in Q. petraea from France and Romania, beingsimilar to that in $Q$. alba. The significant concentration of volatile compounds quantified in toasted oak wood from $Q$. humboldtii with respect to the others suggests that this oak wood may be considered an important source of some volatile compounds. Ellagitannins and volatile composition of the oak woods more than the total low molecular weight phenols concentration allowed the differentiation of $Q$. humboldtii oaks compared to those traditionally used. Toasted $Q$. humboldtii oak wood presented the highest concentration of 5-methyl furfural, furfuryl alcohol, guaiacol, 4-ethylguaiacol, 4vinylguaiacol, cis and trans-isoeugenol, and syringol. Moreover, Colombian oak showed the lowest furfural, 5-hydroxymethylfurfural and cis- $\beta$-methyl- $\gamma$-octalactone concentrations. Thus, $Q$. humboldtii wood volatile composition differed from that of $Q$. petraea and Q. alba.

Considering the results obtained, Colombian $Q$. humboldtii wood can be considered suitable for aging wine, although further study is needed to adapt its treatments in cooperage and to evaluate its potential for oenology.

\section{ACKNOWLEDGEMENTS}

This work was funded by CONICYT, Fondecyt de Iniciación Grant N N 11150462, Chile, and with the collaboration of Tonelería Nacional LTDA, Santiago de Chile. G.G.G. would like to thank the financial support given by CONICYT through BCH/Doctorado - 72170532. This work was financed by the European Regional Development Fund FEDER, Interreg Spain-Portugal Programme, under the framework of the project Iberphenol. We would like to thank Ann Holliday for her services in revising the English.

\section{REFERENCES}

1. Canas SM. Conceição L, Spranger MI and Belchior, AP, Influence of botanical species and geographical origin on the content of low molecular weight phenolic compounds of woods used in Portuguese cooperage. Holzforschunge 54:255-261 (2000).

2. Doussot F, De Jéso B, Quideau S and Pardon P, Extractives content in cooperage oak wood during natural seasoning and toasting; influence of tree species, 
Martínez-Gil, A., Cadahía, E., Fernández de Simón, B., Gutiérrez-Gamboa, G., Nevares, I., \& del Álamo-Sanza, M. (2018). Phenolic and volatile compounds in Quercus humboldtii Bonpl. wood: effect of toasting with respect to oaks traditionally used in cooperage. Journal of the Science of Food and Agriculture. https://doi.org/10.1002/jsfa.9190

geographic location, and single-tree effects. J Agric Food Chem 50:5955-5961 (2002).

3. Prida A and Puech JL, Influence of geographical origin and botanical species on the content of extractives in American, French, and East European oak woods. $J$ Agric Food Chem 54:8115-8126 (2006).

4. Fernández de Simón B, Esteruelas E, Muñoz AM, Cadahía E and Sanz M, Volatile compounds in acacia, chestnut, cherry, ash, and oak woods, with a view to their use in cooperage. J Agric Food Chem 57:3217-3227 (2009).

5. Cadahía E, Fernández de Simón B and Jalocha J, Volatile compounds in Spanish, French and American oak woods after natural seasoning and toasting. J Agric Food Chem 51:5923-5932 (2003).

6. Bozalongo R, Carrillo JD, Fernández-Torroba MA and Tena MT, Analysis of French and American oak chips with different toasting degrees by headspace solid-phase microextraction-gas chromatography-mass spectrometry. $J$ Chromatogr A 1173:10-17 (2007).

7. Cadahía E, Muñoz L, Fernández de Simón B and Garcia-Vallejo MC, Changes in low molecular weight phenolic compounds in Spanish, French, and American oak woods during natural seasoning and toasting. J Agric Food Chem 49:1790-1798 (2001).

8. Garde-Cerdán T and Ancín-Azpilicueta C, Review of quality factors on wine ageing in oak barrels. Trends Food Sci Technol 17:438-447 (2006).

9. Prida A, Use of oak wood in manufacture of barrels for preparing and aging wines. In Oak; ecology, types and management. ed by Cláudio Aleixo Chuteira and Abraham Bispo Grão. Nova publishers, New York, United States, pp. 173-193 (2002).

10. Navarro M, Kontoudakis N, Giordanengo T, Gómez-Alonso S, García-Romero E, Fort $\mathrm{F}$ and Zamora F, Oxygen consumption by oak chips in a model wine solution; influence of the botanical origin, toast level and ellagitannin content. Food Chem 199:822-827 (2016).

11. Alcalde-Eon C, Martínez-Gil AM, Rivas-Gonzalo JC, Escribano-Bailón MT, Nevares I and Del Álamo-Sanza M, An approach to the study of the interactions between ellagitannins and oxygen during oak wood aging. J Agric Food Chem 65:6369-6378 (2017).

12. Glabasnia A and Hofman T, Sensory-directed identification of taste-active ellagitannins in American (Quercus alba L.) and European oak wood (Quercus robur L.) and quantitative analysis in bourbon whiskey and oak-matured red wines. J Agric Food Chem 54:3380-3390 (2006).

13. Stark T, Wollmann N, Wenker K, Lösch S, Glabasnia A and Hofmann T, Matrixcalibrated LC-MS/MS quantitation and sensory evaluation of oak ellagitannins and their transformation products in red wines. J Agric Food Chem 58:6360-6369 (2010).

14. Sáenz-Navajas MP, Fernández-Zurbano $\mathrm{P}$ and Ferreira, V, Contribution of nonvolatile composition to wine flavor. Food Rev Int 28:389-411 (2012).

15. Garde-Cerdán T, Rodríguez-Mozaz S and Ancín-Azpilicueta C, Volatile composition of aged wine in used barrels of French oak and of American oak. Food Res Int 35;603-610 (2002).

16. Jordão AM, Ricardo-Da Silva JM and Laureano O, Comparison of volatile composition of cooperage oak wood of different origins (Quercus pyrenaica vs. Quercus alba and Quercus petrea). Mitt. Klosterneuburg 55:22-31 (2005). 
17. Zhang B, Cai J, Duan CQ, Reeves MJ and He F. A review of polyphenolics in oak woods. Int J Mol Sci 16:6978-7014 (2015).

18. González RE and Baleta LC, Quantification and comparison of ageing markers substances of accelerated aging rums and in oak (Quercus humboldtii) barrels. RVCTA 1:170-183 (2010).

19. González RE, Calderón LS and Cabeza RA, Quantification of aging markers substances in Quercus humboldtii trough high efficiency liquid chromatography. Temas Agrarios 13:56-63 (2008).

20. Martínez-Gil AM, Cadahía E, Fernández de Simón B, Gutiérrez-Gamboa G, Nevares I and Del Álamo Sanza M, Quercus humboldtii (Colombian oak): characterization of oak wood phenolic composition with respect to traditional oak woods in oenology. Ciência Téc Vitiv 32:93-101 (2017).

21. Díaz-Maroto MC, Guchu E, Castro-Vázquez L, de Torres C and Pérez-Coello MS, Aroma active compounds of American, French, Hungarian and Russian oak woods studied by Gas Chromatography-Mass Spectrometry and Gas Chromatography-Olfactometry. Flavour Frag J 23:93-98 (2008).

22. Fernández de Simón B, Cadahía E, Conde E and García-Vallejo MC, Low molecular weight phenolic compounds in Spanish oak woods. J Agric Food Chem 44:1507-1511(1996).

23. Fernández de Simón B, Cadahía E, Conde E and García-Vallejo MC, Ellagitannins in woods of Spanish oaks. J Coop Sci Technol 4:91-98 (1998).

24. Cadahía E, Varea S, Muñoz L, Fernández de Simón B and García-Vallejo MC, Evolution of ellagitannins in Spanish, French, and American oak woods during natural seasoning and toasting. J Agric Food Chem 49:3677-3684 (2001).

25. Chatonnet P, Pons $M$ and Dubourdieu D, Monitoring toasting intensity of barrels by chromatographic analysis of volatile compounds from toasted oak wood. $J$ Agric Food Chem 47:4310-4318 (1999).

26. López R, Aznar M, Cacho J and Ferreira V, Determination of minor and trace volatile compounds in wine by solid-phase extraction and gas chromatography with mass spectrometric detection. J Chromatogr A 966:167-177 (2002).

27. Sanz M, Fernández de Simón B, Esteruelas E, Muñoz AM, Cadahía E, Hernández, T, Estrella I and Pinto E, Effect of toasting intensity at cooperage on phenolic compounds in acacia (Robinia pseudoacacia) heartwood. J Agric Food Chem 59:3135-3145 (2001).

28. Martinez R.G, Mir MV, Serrana HLG, Martinez, MCL and Herrera O Simultaneous determination of vanillin and syringaldehyde using high performance liquid chromatography. Application to the static and soleras aged brandies. J Liq Chromatogr 16:4079-4094 (1993).

29. De Aquino FWB, Rodrigues S, Do Nascimento RF and Casimiro ARS, Simultaneous determination of aging markers in sugarcane spirits. Food Chem 98:569-574 (2006).

30. Puech JL, Extraction of phenolic compounds from oak wood in model solutions and evolution of aromatic aldehydes in wines aged in oak barrels. Am J Enol Vitic 38:236-238 (1987).

31. Puech JL and Jouret C, Dosage des aldéydes aromatiques des eaux-de-vie conservées en futs de chene: Detection d'adulteration. Ann Fals Expert Chim 75:81-90 (1982).

32. Jordão AM, Ricado-Da Silva JM and Laureano O, Ellagitannins from Portuguese oak wood (Quercus pyrenaica Willd.) used in cooperage: Influence of 
geographical origin, coarseness of the grain and toasting level. Holzforschung 61:155-160 (2007).

33. Matricardi L and Waterhouse AL, Influence of toasting technique on color and ellagitannins of oak wood in barrel making. Am J Enol Vitic 50:519-526 (1999).

34. Rodríguez-Bencomo JJ, Ortega-Heras M, Pérez-Magariño S and GonzálezHuerta C, Volatile compounds of red wines macerated with Spanish, American, and French oak chips. J Agric Food Chem 57:6383-6391(2009).

35. Spillman PJ, Sefton MA and Gawel R, The effect of oak wood source, location of seasoning and coopering on the composition of volatile compounds in oakmatured wines. Aust J Grape Wine Res 10:216-226 (2004).

36. Pérez-Coello MS, Sanz J and Cabezudo MD, Determination of volatile compounds in hydroalcoholic extracts of French and American Oak Wood. Am J Enol Vitic 50:162-165 (1999).

37. Chatonnet $\mathrm{P}$ and Dubourdieu D, Comparative study of the characteristics of American White Oak (Quercus alba) and European Oak (Quercus petraea and Q. robur) for production of barrels used in barrel aging of wines. Am J Enol Vitic 49:79-85 (1998).

38. Natali N, Chinnici F and Riponi C, Characterization of volatiles in extracts from oak chips obtained by Accelerated Solvent Extraction (ASE). J Agric Food Chem 54:8190-8198 (2006).

39. Cadahía E and Fernández de Simón B. In Utilización de roble español en el envejecimiento de vino. Comparación con roble francés y americano, ed by Instituto Nacional de Investigación Agraria y Alimentaria. Ministerio de Educación y Ciencia, Madrid, España, Vol. 10, pp. 136 (2004). 
Martínez-Gil, A., Cadahía, E., Fernández de Simón, B., Gutiérrez-Gamboa, G., Nevares, I., \& del Álamo-Sanza, M. (2018).

Phenolic and volatile compounds in Quercus humboldtii Bonpl. wod: effect of toasting with respect to oaks traditionally

used in cooperage. Journal of the Science of Food and Agriculture. https://doi.org/10.1002/jsfa.9190

Table 1. Low molecular weight phenolic compounds concentration ( $\mu \mathrm{g} \mathrm{g}^{-1}$ of wood) obtained in wood of Quercus petraea (French and Romanian oak), Quercus alba (American oak) and Quercus humboldtii (Colombian oak) after seasoning (non-toasted) and already toasted

\begin{tabular}{|c|c|c|c|c|}
\hline & \multicolumn{2}{|c|}{ Q. petraea } & \multirow{2}{*}{$\begin{array}{c}\text { Q. } \boldsymbol{a l} \boldsymbol{l} \boldsymbol{b a} \\
\text { American Oak }\end{array}$} & \multirow{2}{*}{$\begin{array}{c}\text { Q. humboldtii } \\
\text { Colombian oak }\end{array}$} \\
\hline & French oak & Romanian oak & & \\
\hline & & Non-toasted & & \\
\hline \multicolumn{5}{|l|}{ Acids } \\
\hline Ellagic acid & $613.19 \pm 44.88 a$ & $597.74 \pm 58.13 \mathrm{a}$ & $419.94 \pm 90.05 \mathrm{a}$ & $562.05 \pm 193.61 \mathrm{a}$ \\
\hline Gallic acid & $139.28 \pm 43.12$ c & $70.90 \pm 30.01 \mathrm{~b}$ & $8.51 \pm 1.24 \mathrm{a}$ & $244.05 \pm 26.39 \mathrm{~d}$ \\
\hline Syringic acid & $8.15 \pm 0.73 c$ & $6.33 \pm 0.88 b$ & $6.54 \pm 0.80 b$ & $3.49 \pm 0.52 \mathrm{a}$ \\
\hline Vanillic acid & $7.95 \pm 0.53 \mathrm{c}$ & $4.07 \pm 0.66 \mathrm{a}$ & $6.59 \pm 0.75 b$ & $4.05 \pm 0.08 \mathrm{a}$ \\
\hline Total acids & $768.57 \pm 62.24 b$ & $679.04 \pm 9.64 b$ & $441.58 \pm 20.40 a$ & $813.64 \pm 195.40 b$ \\
\hline \multicolumn{5}{|l|}{ Aldehydes } \\
\hline Coniferyl aldehyde & $3.74 \pm 0.40 b$ & $2.91 \pm 0.34 \mathrm{a}$ & $3.99 \pm 0.33 b$ & $2.47 \pm 0.05 \mathrm{a}$ \\
\hline Sinapic aldehyde & $6.41 \pm 0.66 \mathrm{c}$ & $3.42 \pm 0.38 \mathrm{a}$ & $5.28 \pm 0.51 b$ & $10.18 \pm 0.29 \mathrm{~d}$ \\
\hline Syringic aldehyde & $12.13 \pm 0.41 b$ & $8.90 \pm 1.19 a b$ & $18.15 \pm 4.27 \mathrm{c}$ & $5.51 \pm 0.39 \mathrm{a}$ \\
\hline Total aldehydes & $22.27 \pm 1.10 \mathrm{~b}$ & $15.23 \pm 1.56 \mathrm{a}$ & $27.42 \pm 4.36 \mathrm{c}$ & $18.16 \pm 0.60 \mathrm{ab}$ \\
\hline \multicolumn{5}{|c|}{ Toasted } \\
\hline \multicolumn{5}{|l|}{ Acids } \\
\hline Ellagic acid & $1012.05 \pm 233.90 b$ & $786.61 \pm 199.45 \mathrm{ab}$ & $641.69 \pm 45.72 \mathrm{a}$ & $552.53 \pm 99.36 \mathrm{a}$ \\
\hline Gallic acid & $157.27 \pm 34.74 \mathrm{~b}$ & $160.98 \pm 31.01 \mathrm{~b}$ & $69.87 \pm 12.97 \mathrm{a}$ & $78.27 \pm 13.85 a$ \\
\hline Syringic acid & $26.11 \pm 5.18 \mathrm{ab}$ & $24.59 \pm 5.39 \mathrm{a}$ & $19.82 \pm 2.13 \mathrm{a}$ & $33.84 \pm 3.18 b$ \\
\hline Vanillic acid & $10.79 \pm 1.14 \mathrm{a}$ & $13.07 \pm 2.44 \mathrm{a}$ & $13.86 \pm 1.94 \mathrm{a}$ & $21.06 \pm 1.10 \mathrm{~b}$ \\
\hline Total acids & $1206.22 \pm 261.78 b$ & $985.24 \pm 237.16 \mathrm{ab}$ & $745.24 \pm 51.28 \mathrm{a}$ & $685.71 \pm 116.50 \mathrm{a}$ \\
\hline \multicolumn{5}{|l|}{ Aldehydes } \\
\hline Coniferyl aldehyde & $428.41 \pm 98.88 \mathrm{a}$ & $339.54 \pm 72.42 \mathrm{a}$ & $513.97 \pm 122.29 \mathrm{a}$ & $485.45 \pm 60.62 \mathrm{a}$ \\
\hline Sinapic aldehyde & $1162.04 \pm 234.30 \mathrm{a}$ & $867.44 \pm 151.86 \mathrm{a}$ & $1007.98 \pm 207.35$ a & $1181.60 \pm 104.50 \mathrm{a}$ \\
\hline Syringic aldehyde & $78.68 \pm 12.20 \mathrm{a}$ & $70.86 \pm 14.42 \mathrm{a}$ & $86.23 \pm 16.60 \mathrm{ab}$ & $110.93 \pm 8.64 b$ \\
\hline Total aldehydes & $1669.14 \pm 343.77 \mathrm{a}$ & $1277.83 \pm 233.92 \mathrm{a}$ & $1608.18 \pm 346.20 \mathrm{a}$ & $1817.15 \pm 166.25 \mathrm{a}$ \\
\hline
\end{tabular}

All parameters are given with their standard deviation $(n=3)$. Different letters in the same column indicate significant differences $(p<0.05)$ between

the different oak woods. 
Table 2. Ellagitannin concentration ( $\mu \mathrm{g} \mathrm{g}^{-1}$ of wood) obtained in wood of Quercus petraea (French and Romanian oak), Quercus alba (American oak) and Quercus humboldtii (Colombian oak) after seasoning and after toasting

\begin{tabular}{|c|c|c|c|c|}
\hline & \multicolumn{2}{|c|}{ Q. petraea } & \multirow{2}{*}{$\begin{array}{c}\text { Q. alba } \\
\text { American Oak }\end{array}$} & Q. humboldtii \\
\hline & French oak & Romanian oak & & Colombian oak \\
\hline \multicolumn{5}{|c|}{ Non-toasted } \\
\hline \multicolumn{5}{|l|}{ Monomers } \\
\hline Castalagin & $9941.73 \pm 1200.14 \mathrm{c}$ & $7455.44 \pm 2215.01 b$ & $1357.86 \pm 86.68 \mathrm{a}$ & $541.81 \pm 75.28 \mathrm{a}$ \\
\hline Vescalagin & $11763.17 \pm 2645.92$ c & $6643.83 \pm 2051.53 b$ & $895.62 \pm 52.50 \mathrm{a}$ & $272.03 \pm 36.94 \mathrm{a}$ \\
\hline \multicolumn{5}{|c|}{ pentosylated monomers } \\
\hline Grandinin & $1878.33 \pm 155.54 \mathrm{~b}$ & $1976.19 \pm 505.07 \mathrm{~b}$ & $357.39 \pm 45.16 \mathrm{a}$ & $224.65 \pm 20.72 \mathrm{a}$ \\
\hline Roburin E & $3294.31 \pm 501.52$ c & $23211.44 \pm 680.49 \mathrm{~b}$ & $299.72 \pm 24.89 \mathrm{a}$ & $165.51 \pm 23.46 \mathrm{a}$ \\
\hline \multicolumn{5}{|l|}{ Dimers } \\
\hline Roburin $\mathrm{A}+\mathrm{B}$ & $1997.08 \pm 325.30 \mathrm{c}$ & $1355.27 \pm 298.30 b$ & $176.82 \pm 25.4 \mathrm{a}$ & $35.59 \pm 5.64 \mathrm{a}$ \\
\hline \multicolumn{5}{|c|}{ pentosylated dimers } \\
\hline Roburin C & $303.55 \pm 27.89 c$ & $279.78 \pm 20.57 \mathrm{c}$ & $202.36 \pm 6.76 b$ & $45.12 \pm 2.67 \mathrm{a}$ \\
\hline Roburin D & $4679.15 \pm 614.07 \mathrm{~b}$ & $3862.19 \pm 1036.34$ b & $843.73 \pm 48.83 a$ & $320.44 \pm 33.38 \mathrm{a}$ \\
\hline \multirow[t]{2}{*}{ Total ellagitanins } & $33857.31 \pm 3033.26 \mathrm{c}$ & $23894.14 \pm 3316.12 b$ & $4133.49 \pm 126.51 \mathrm{a}$ & $1605.16 \pm 95.62 \mathrm{a}$ \\
\hline & & Toasted & & \\
\hline \multicolumn{5}{|l|}{ Monomers } \\
\hline Castalagin & $3344.38 \pm 1314.90 \mathrm{c}$ & $1975.80 \pm 152.21 b$ & $346.57 \pm 154.81 \mathrm{a}$ & $17.05 \pm 19.90 \mathrm{a}$ \\
\hline Vescalagin & $1455.92 \pm 600.01 c$ & $869.99 \pm 71.06 \mathrm{~b}$ & $82.10 \pm 40.65 \mathrm{a}$ & $12.78 \pm 9.11 \mathrm{a}$ \\
\hline \multicolumn{5}{|c|}{ pentosylated monomers } \\
\hline Grandinin & $85.73 \pm 45.03 \mathrm{a}$ & $305.47 \pm 66.63 b$ & $41.14 \pm 9.95 \mathrm{a}$ & $25.33 \pm 6.97 \mathrm{a}$ \\
\hline Roburin E & $302.41 \pm 210.58 b$ & $163.51 \pm 40.17 \mathrm{ab}$ & $17.48 \pm 16.48 \mathrm{a}$ & $11.12 \pm 4.91 \mathrm{a}$ \\
\hline \multicolumn{5}{|l|}{ Dimers } \\
\hline Roburin $A+B$ & $238.97 \pm 96.06 c$ & $140.49 \pm 10.24 b$ & $18.62 \pm 2.50 \mathrm{a}$ & $3.82 \pm 0.53 \mathrm{a}$ \\
\hline \multicolumn{5}{|c|}{ pentosylated dimers } \\
\hline Roburin C & $29.80 \pm 18.05$ bc & $41.02 \pm 11.48 \mathrm{c}$ & $9.65 \pm 2.95 \mathrm{ab}$ & $1.08 \pm 0.89 \mathrm{a}$ \\
\hline Roburin D & $377.39 \pm 283.48 b$ & $183.71 \pm 76.11 \mathrm{ab}$ & $36.76 \pm 9.86 \mathrm{a}$ & $43.97 \pm 8.12 \mathrm{a}$ \\
\hline Total ellagitanins & $5834.59 \pm 1491.72$ b & $3679.98 \pm 200.75 b$ & $552.33 \pm 161.55 a$ & $115.15 \pm 24.87 \mathrm{a}$ \\
\hline
\end{tabular}

All parameters are given with their standard deviation $(n=3)$. Different letters in the same column indicate significant differences $(\mathrm{p}<0.05)$ between the different oak woods. 
Martínez-Gil, A., Cadahía, E., Fernández de Simón, B., Gutiérrez-Gamboa, G., Nevares, I., \& del Álamo-Sanza, M. (2018).

Phenolic and volatile compounds in Quercus humboldtii Bonpl. wood: ffect of toasting with respect to oaks traditionally

used in cooperage. Journal of the Science of Food and Agriculture. https://doi.org/10.1002/jsfa.9190

Table 3. Volatile composition ( $\mu \mathrm{g} \mathrm{g}^{-1}$ of wood) obtained in wood of Quercus petraea (French and Romanian oak), Quercus alba (American oak) and Quercus humboldtii (Colombian oak) after seasoning and toasting

\begin{tabular}{|c|c|c|c|c|}
\hline & \multicolumn{2}{|c|}{ Q. petraea } & \multirow{2}{*}{$\begin{array}{c}\text { Q. alba } \\
\text { American oak }\end{array}$} & \multirow{2}{*}{$\begin{array}{l}\text { Q. humboldtii } \\
\text { Colombian oak }\end{array}$} \\
\hline & French oak & Romanian oak & & \\
\hline \multicolumn{5}{|c|}{ Non-toasted } \\
\hline furfural & nd & nd & nd & nd \\
\hline 5-methylfurfural & $0.34 \pm 0.51 \mathrm{a}$ & $2.09 \pm 0.58 b$ & $2.25 \pm 0.19 b$ & $2.76 \pm 0.29 b$ \\
\hline 5-hydroxymethylfurfural & $13.99 \pm 3.45 b$ & $15.23 \pm 3.63 b$ & $3.83 \pm 1.05 \mathrm{a}$ & nd \\
\hline furfuryl alcohol & $1.07 \pm 0.09 \mathrm{a}$ & $1.01 \pm 0.04 \mathrm{a}$ & $0.97 \pm 0.04 \mathrm{a}$ & $0.97 \pm 0.02 \mathrm{a}$ \\
\hline trans- $\beta$-methyl- $\gamma$-octalactone & $1.82 \pm 0.10 \mathrm{a}$ & $13.24 \pm 6.47 b$ & $4.99 \pm 0.36 a$ & nd \\
\hline cis- $\beta$-methyl- $\gamma$-octalactone & $5.93 \pm 6.08 \mathrm{a}$ & $7.67 \pm 4.30 \mathrm{a}$ & $50.15 \pm 20.96 b$ & $0.02 \pm 0.00 \mathrm{a}$ \\
\hline guaiacol & nd & nd & $0.05 \pm 0.01 \mathrm{~b}$ & $0.10 \pm 0.01 c$ \\
\hline 4-ethylguaiacol & $0.03 \pm 0.00 \mathrm{a}$ & $0.03 \pm 0.01 \mathrm{a}$ & $0.03 \pm 0.00 \mathrm{a}$ & $0.04 \pm 0.01 \mathrm{a}$ \\
\hline 4-vinylguaiacol & $0.50 \pm 0.01 \mathrm{a}$ & $0.50 \pm 0.04 \mathrm{a}$ & $0.51 \pm 0.06 \mathrm{a}$ & $0.49 \pm 0.07 \mathrm{a}$ \\
\hline eugenol & $0.46 \pm 0.22 \mathrm{a}$ & $2.04 \pm 1.55 b$ & $1.85 \pm 0.03 \mathrm{ab}$ & $2.65 \pm 0.08 b$ \\
\hline cis-isoeugenol & $0.21 \pm 0.03 \mathrm{a}$ & $0.20 \pm 0.04 a$ & $0.22 \pm 0.09 \mathrm{a}$ & $0.22 \pm 0.01 \mathrm{a}$ \\
\hline trans-isoeugenol & $0.69 \pm 0.01 \mathrm{a}$ & $0.69 \pm 0.01 \mathrm{a}$ & $0.73 \pm 0.02 a$ & $0.95 \pm 0.06 b$ \\
\hline syringol & $0.08 \pm 0.00 \mathrm{a}$ & $0.10 \pm 0.01 b$ & $0.09 \pm 0.01 \mathrm{ab}$ & $0.09 \pm 0.00 \mathrm{ab}$ \\
\hline vanillin & $6.06 \pm 0.66 b$ & $5.81 \pm 0.80 b$ & $10.58 \pm 2.18 c$ & $1.97 \pm 0.19 \mathrm{a}$ \\
\hline acetovanillone & $0.29 \pm 0.04 \mathrm{a}$ & $0.31 \pm 0.02 \mathrm{a}$ & $0.42 \pm 0.07 b$ & $0.26 \pm 0.01 \mathrm{a}$ \\
\hline benzaldehyde & $0.07 \pm 0.02 \mathrm{a}$ & $0.05 \pm 0.02 \mathrm{a}$ & $1.06 \pm 0.15 b$ & $0.05 \pm 0.01 \mathrm{a}$ \\
\hline 2-phenylethanol & $0.73 \pm 0.28 a$ & $0.40 \pm 0.03 a$ & $1.79 \pm 0.91 b$ & $0.25 \pm 0.09 a$ \\
\hline Total volatile & $32.28 \pm 3.55 \mathrm{ab}$ & $49.38 \pm 4.79 \mathrm{bc}$ & $79.50 \pm 12.01 \mathrm{c}$ & $10.81 \pm 0.95 \mathrm{a}$ \\
\hline \multicolumn{5}{|c|}{ Toasted } \\
\hline furfural & $924.15 \pm 129.00 \mathrm{~b}$ & $1149.63 \pm 162.83 \mathrm{c}$ & $1363.16 \pm 41.56 \mathrm{~d}$ & $533.53 \pm 26.20 \mathrm{a}$ \\
\hline 5-methylfurfural & $27.74 \pm 4.55 b$ & $23.41 \pm 5.05 a b$ & $16.92 \pm 2.00 \mathrm{a}$ & $45.40 \pm 1.32 \mathrm{c}$ \\
\hline 5-hydroxymethylfurfural & $579.01 \pm 76.76 \mathrm{ab}$ & $1191.90 \pm 285.05 c$ & $804.27 \pm 59.41 \mathrm{~b}$ & $463.42 \pm 38.03 \mathrm{a}$ \\
\hline furfuryl alcohol & $1.20 \pm 0.04 \mathrm{a}$ & $1.56 \pm 0.06 \mathrm{a}$ & $1.50 \pm 0.09 \mathrm{a}$ & $12.32 \pm 0.45 b$ \\
\hline trans- $\beta$-methyl- $\gamma$-octalactone & $2.05 \pm 0.21 \mathrm{a}$ & $19.51 \pm 9.75 b$ & $3.47 \pm 0.42 \mathrm{a}$ & $0.06 \pm 0.01 \mathrm{a}$ \\
\hline
\end{tabular}


Martínez-Gil, A., Cadahía, E., Fernández de Simón, B., Gutiérrez-Gamboa, G., Nevares, I., \& del Álamo-Sanza, M. (2018).

Phenolic and volatile compounds in Quercus humboldtii Bonpl. wood: effect of toasting with respect to oaks traditionally

used in cooperage. Journal of the Science of Food and Agriculture. https://doi.org/10.1002/jsfa.9190

$\begin{array}{cc}\text { cis- } \beta \text {-methyl- } \gamma \text {-octalactone } & 12.65 \pm 1.41 \mathrm{~b} \\ \text { guaiacol } & 0.40 \pm 0.03 \mathrm{a} \\ \text { 4-ethylguaiacol } & 0.14 \pm 0.01 \mathrm{a} \\ \text { 4-vinylguaiacol } & 0.49 \pm 0.01 \mathrm{a} \\ \text { eugenol } & 1.60 \pm 0.21 \mathrm{a} \\ \text { cis-isoeugenol } & 1.74 \pm 0.11 \mathrm{a} \\ \text { trans-isoeugenol } & 1.96 \pm 0.05 \mathrm{a} \\ \text { syringol } & 1.43 \pm 0.08 \mathrm{a} \\ \text { vanillin } & 22.54 \pm 3.89 \mathrm{a} \\ \text { acetovanillone } & 1.44 \pm 0.19 \mathrm{a} \\ \text { benzaldehyde } & 0.16 \pm 0.01 \mathrm{a} \\ \text { 2-phenylethanol } & 0.27 \pm 0.09 \mathrm{a} \\ \text { Total volatile } & 1578.96 \pm 255.45 \mathrm{a}\end{array}$

$13.27 \pm 7.28 \mathrm{~b}$
$0.55 \pm 0.12 \mathrm{a}$
$0.11 \pm 0.01 \mathrm{a}$
$0.51 \pm 0.02 \mathrm{ab}$
$5.59 \pm 0.50 \mathrm{~b}$
$2.11 \pm 0.62 \mathrm{a}$
$2.24 \pm 0.39 \mathrm{a}$
$1.92 \pm 0.52 \mathrm{a}$
$23.18 \pm 0.80 \mathrm{a}$
$1.34 \pm 0.10 \mathrm{a}$
$0.15 \pm 0.01 \mathrm{a}$
$0.43 \pm 0.13 \mathrm{a}$

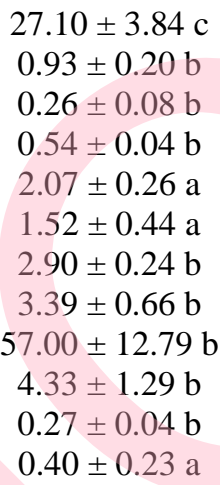

$0.30 \pm 0.09$

$3.74 \pm 0.26 \mathrm{c}$

$0.61 \pm 0.02 c$

$0.67 \pm 0.03 \mathrm{c}$

$3.34 \pm 0.19 b$

$7.23 \pm 0.49 b$

$5.39 \pm 0.30 \mathrm{c}$

$10.14 \pm 0.87 \mathrm{c}$

$22.36 \pm 1.21 \mathrm{a}$

$2.29 \pm 0.20$

$0.40 \pm 0.23 \mathrm{a}$

$0.17 \pm 0.01 \mathrm{a}$

$2437.42 \pm 386.85 \mathrm{~b}$

$2290.02 \pm 370.89 \mathrm{~b}$

$1111.37 \pm 163.88 \mathrm{a}$

All parameters are given with their standard deviation $(\mathrm{n}=3)$. Different letters in the same column indicate significant differences $(\mathrm{p}<0.05)$ between the different oak woods. nd=not detected. 
Figure 1. Principal Component analysis results carried out with all low molecular weight phenolic compounds found in Quercus petraea, (French and Romanian) Q. alba, (American), and Q humboldtii (Colombian) oak woods. PCA of non-toasted wood (figure 1a) and PCA of toasted wood (figure 1b).

a)

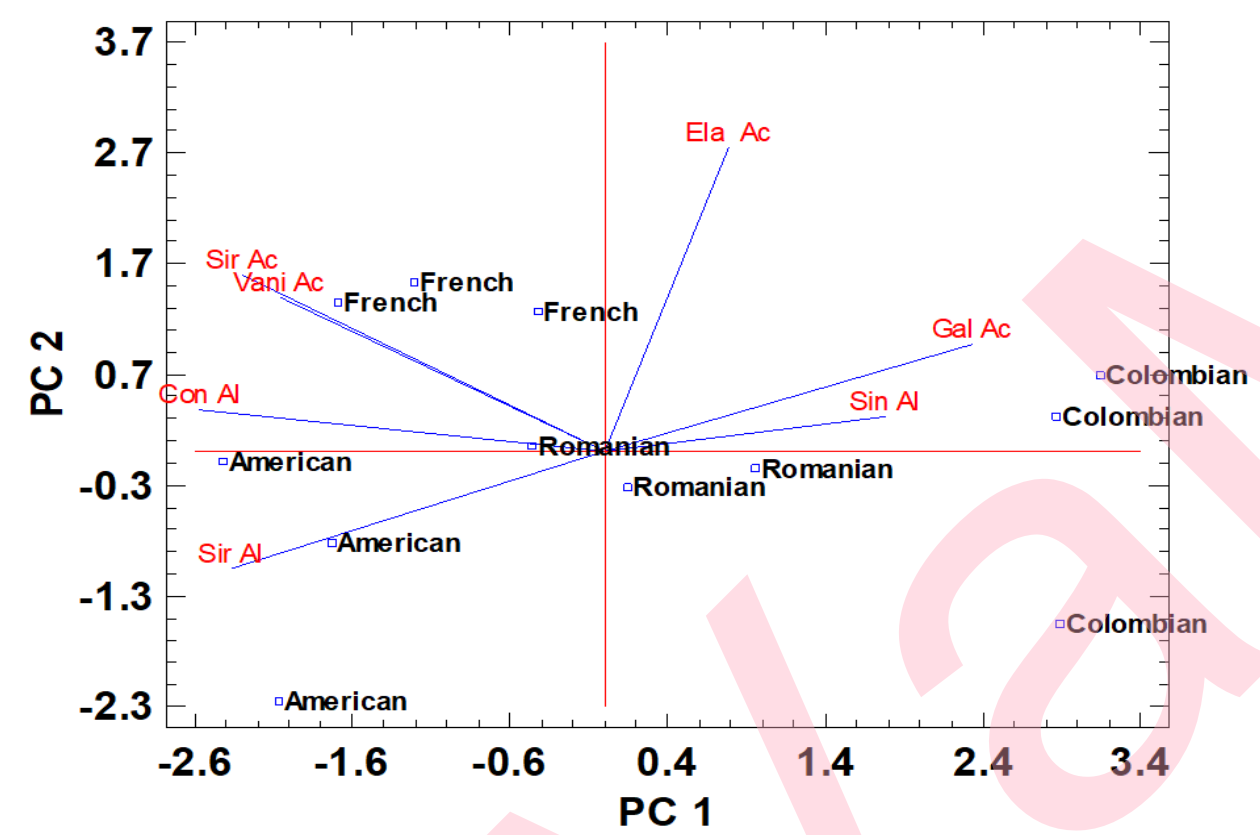

b)

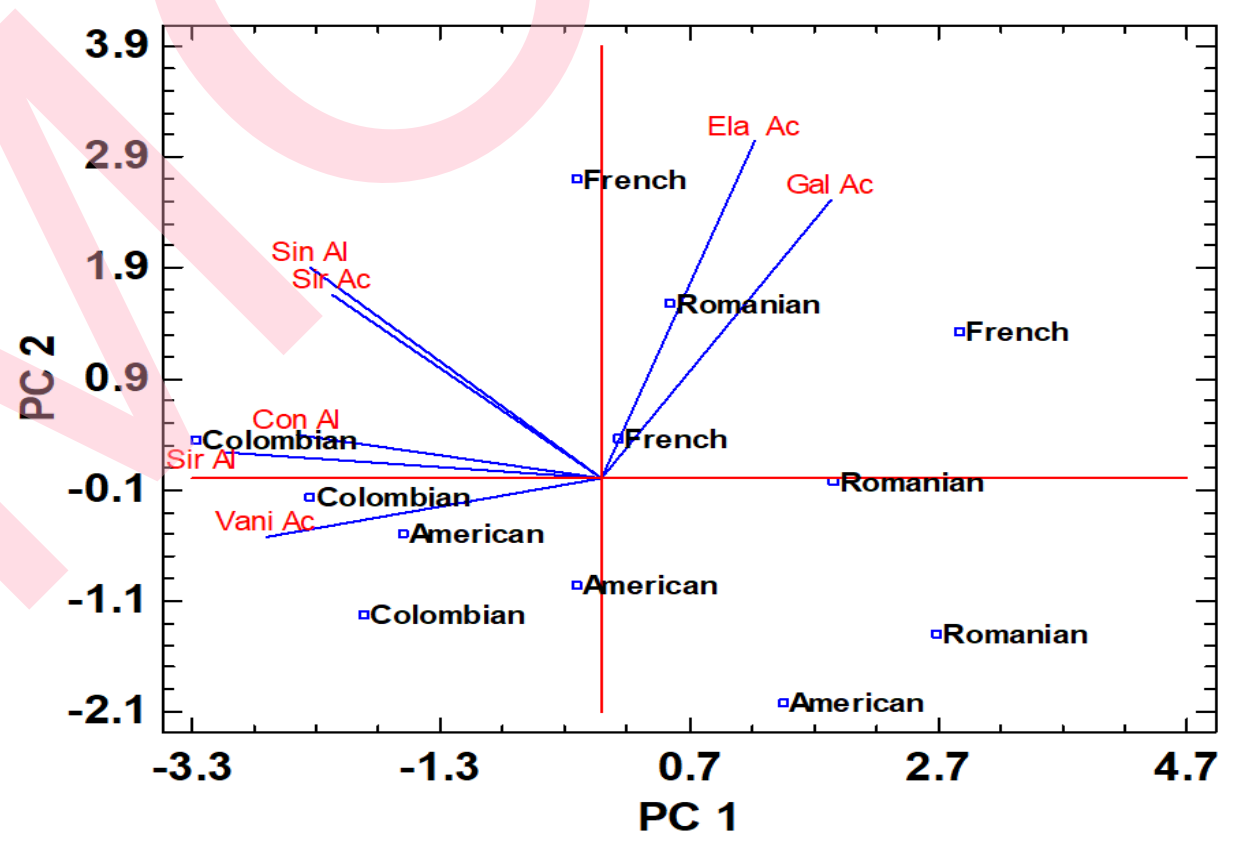


Figure 2. Principal Component analysis results carried out with all ellagitannins found in Quercus petraea, (French and Romanian) Q. alba, (American), and $Q$ humboldtii (Colombian) oak woods. PCA of non-toasted wood (figure 2a) and PCA of toasted wood (figure 2b).
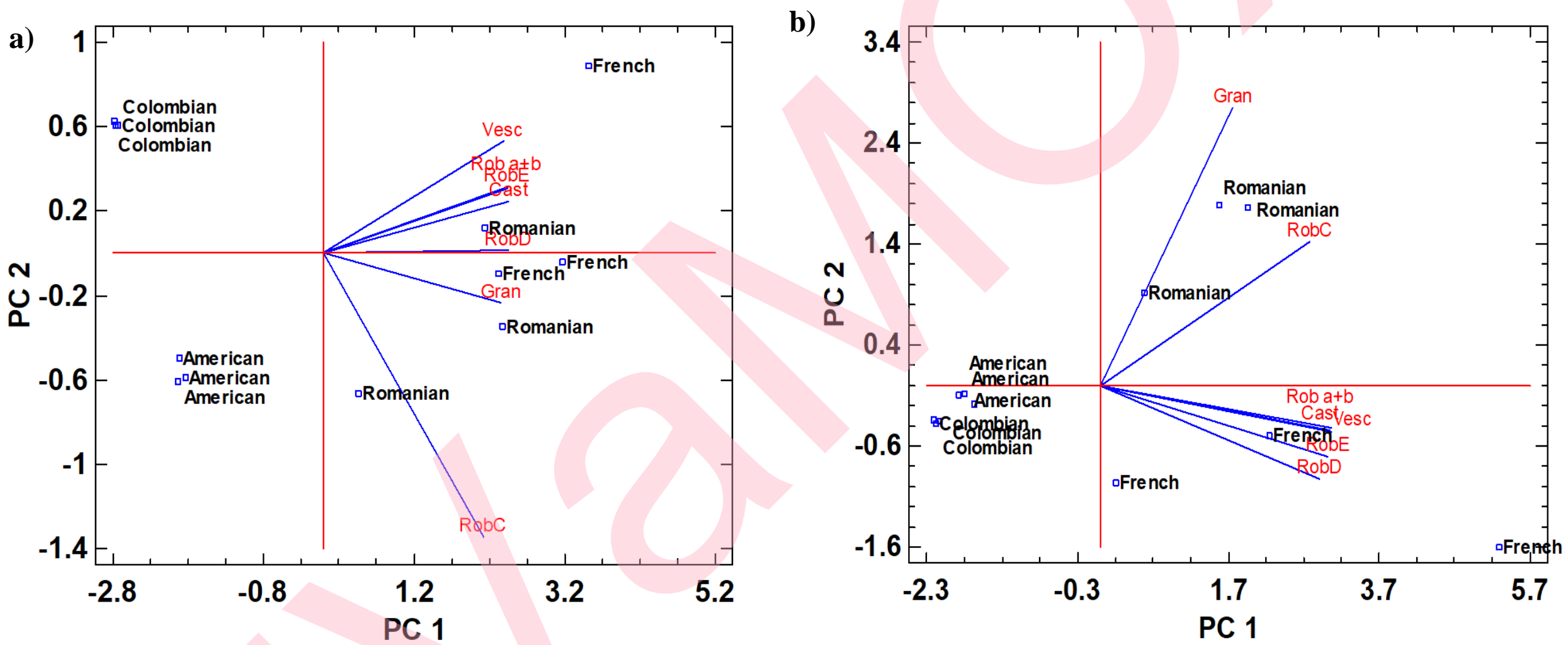
Figure 3. Principal Component analysis results carried out with all volatile compounds found in Quercus petraea, (French and Romanian) Q. alba, (American), and $Q$ humboldtii (Colombian) oak woods. PCA of non-toasted wood (figure 3a) and PCA of toasted wood (figure 3b).

a)

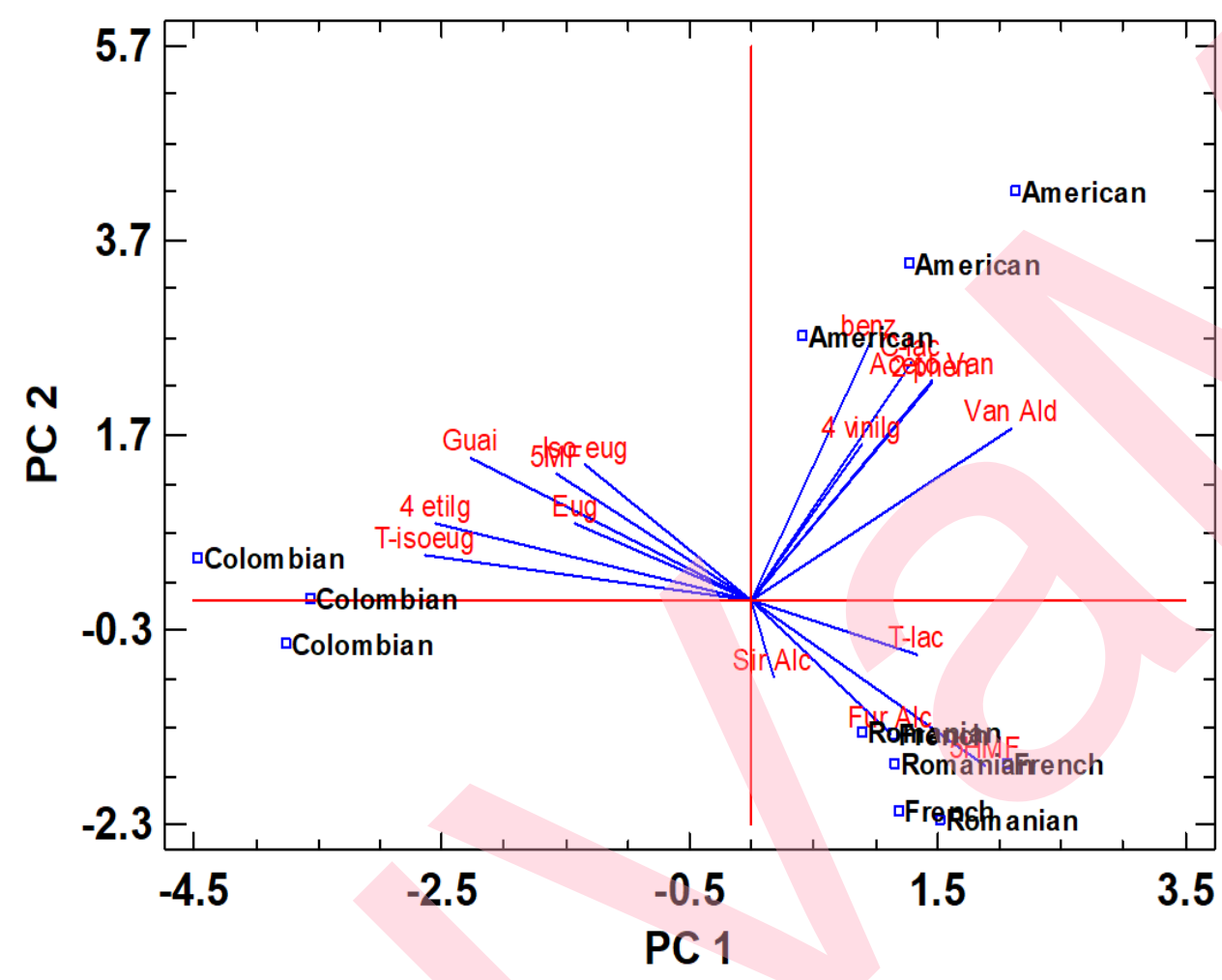

b)

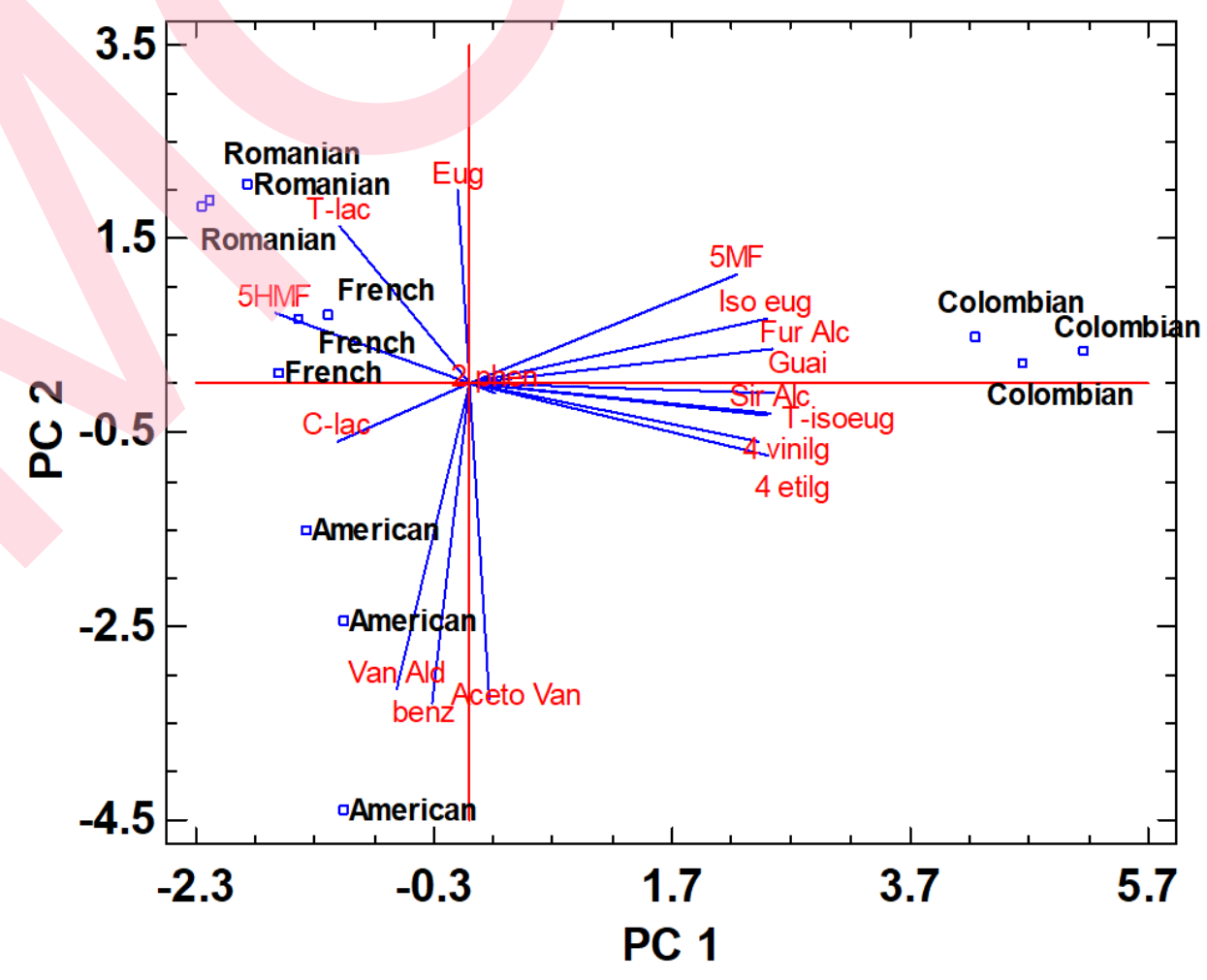

